\title{
Porównanie wpływu tlenu resztkowego w gazie formującym na wybrane właściwości złączy stali 304L oraz 316L spawanych TIG orbitalnie
}

\author{
Comparison of the effect of residual oxygen in the forming gas \\ on selected properties of 304L and 316L steel \\ joint welded by orbital TIG
}

\section{Streszczenie}

W pracy opisano wpływ stężenia tlenu resztkowego w gazie formującym na wybrane właściwości spoin czołowych stali 304L oraz 316L wykonanych metodą spawania orbitalnego TIG. Przeprowadzono próby spawania z gazem formującym $\mathrm{Ar} z$ zawartością tlenu na poziomie $6 \mathrm{ppm}$ oraz 500 ppm. Uzyskane złącza porównano pod względem budowy strukturalnej oraz rozkładów twardości.

Słowa kluczowe: spawanie orbitalne TIG; stal 304L; stal 316L

\begin{abstract}
This paper describes the effect of the concentration of residual oxygen in the forming gas on selected properties of the butt weld of steel 304L and 316 L made by orbital TIG welding method. Welding tests were conducted in Argonium forming gas with oxygen content of $6 \mathrm{ppm}$ and $500 \mathrm{ppm}$. The resulting joints were compared in terms of structural composition, geometry and hardness distribution.
\end{abstract}

Keywords: orbital TIG welding; steel 304L; steel 316L

\section{Wstęp}

Metoda TIG jest najczęściej stosowaną metodą łączenia rurociągów ze stali wysokostopowych. Pomimo trudności z automatyzacją metody TIG, opracowano zautomatyzowaną odmianę orbitalną TIG. Jest to odpowiedź na ciągle rosnące wymagania jakościowe oraz oczekiwania wyższej wydajności spawania niż podczas spawania ręcznego. Wprowadzenie automatyzacji nastręcza jednak wielu trudności dotyczących chociażby zapewnienia powtarzalnych właściwości "styku” przygotowanego złącza, na zmianę których, spawacz operujący ręcznie reaguje odpowiednio w czasie rzeczywistym. Spawanie orbitalne jest procesem zautomatyzowanym, realizowanym za pośrednictwem specjalnie przystosowanych do tego celu głowic spawalniczych przemieszczających się względem nieruchomego złącza. Technika spawania orbitalnego jest wykorzystywana $\mathrm{m}$.in. do wykonywania rurociągów, wężownic i innych konstrukcji rurowych. W technice spawania orbitalnego mogą być wykorzystywane różne metody spawania (najczęściej TIG). W przypadku elementów rurowych o grubości ścianki do $2 \mathrm{~mm}$ proces spawania TIG może być prowadzony bez dodatku spoiwa, podczas spawania elementów o większej grubości, materiał dodatkowy jest stosowany [1 $\div 5]$.

Celem pracy jest porównanie wpływu obecność tlenu w gazie formującym na właściwości złączy dwóch popularnych gatunków stali nierdzewnych. Oprócz wspomnianej wcześniej ochrony przed utlenianiem, drugim ważnym powodem stosowania gazu formującego jest kształtowanie struktury stereometrycznej powierzchni grani, określane mianem formowania grani. Ze względu na wysoką cenę czysty argon powinien być stosowany do formowania grani tylko w uzasadnionych przypadkach. Tańsza od argonu jest mieszanka azotu z wodorem, lecz podwyższa ryzyko wystąpienia pęknięć, zwłaszcza kiedy stal wykazuje skłonność do utwardzenia w SWC. W związku z tym, gazem zalecanym i najczęściej stosowanym do ochrony lica oraz grani podczas spawania metodą TIG austenitycznej stali $\mathrm{Cr}-\mathrm{Ni}$ jest argon lub jego mieszanka z wodorem (do ok. 5\%).

Wpływ tlenu w gazie osłonowym/formującym na właściwości spoiny jest bardzo istotny.

Mgr inż. Marcin Drabarz - MDTechnology; dr hab. inż. Tomasz Chmielewski, prof. PW; dr hab. inż. Dariusz Golański, prof. PW - Politechnika Warszawska

Autor korespondencyjny/Corresponding author. t.chmielewski@wip.pw.edu.pl 
Podczas procesu spawania stali zawsze należy liczyć się z oddziaływaniem tlenu na jeziorko ciekłego metalu. Intensywność utleniania zależy od składu atmosfery oraz temperatury ośrodka i zawsze zachodzi w przestrzeni łukowej i w kąpieli metalu. Silniej od strony lica i dużo słabiej od strony grani $[1 \div 6]$. Ze względu na konwekcyjny ruch cieczy w kąpieli metalicznej, produkty utleniania mogą docierać głębiej pod powierzchnię. W orbitalnej odmianie spawania TIG stosowana jest obojętna chemicznie osłona gazowa lica w postaci argonu lub helu. Ma ona za zadanie zapobiegać zachodzeniu niepożądanych reakcji pomiędzy kąpielą metaliczną a otaczającą atmosferą oraz zapobiegać utlenianiu elektrody. Stosowana jest także osłona grani w postaci gazu formującego, którym może być argon, hel, azot lub ich domieszki np. z wodorem o udziale do 5\%. Pomimo stosowania ochrony gazowej cząsteczki tlenu mogą przedostać się do obszaru kąpieli metalicznej. Utlenianie może być również spowodowane pośrednio poprzez tlenki znajdujące się na powierzchni materiałów spawanych. Utlenianiu podlegają wszystkie składniki stopowe metalu, jednakże w zależności od ich powinowactwa do tlenu, następuje to z różną intensywnością. Tlen powoduje również zmianę napięcia powierzchniowego jeziorka ciekłego metalu i może powodować zubożenie metalu z dodatków stopowych np. chrom. Obniża to odporność korozyjną stali. $Z$ tego powodu dla typowych austenitycznych stali chromowo-niklowych gat. 304 zawartość tlenu w gazie formującym nie powinna przekraczać 20 ppm. W przypadku stali gat. $316 \mathrm{~L}$ utrata właściwości antykorozyjnych na skutek tworzenia się wysokotemperaturowych tlenków chromu następuje, jeżeli ilość tlenu w gazie osłonowym przekracza 50 ppm [6].

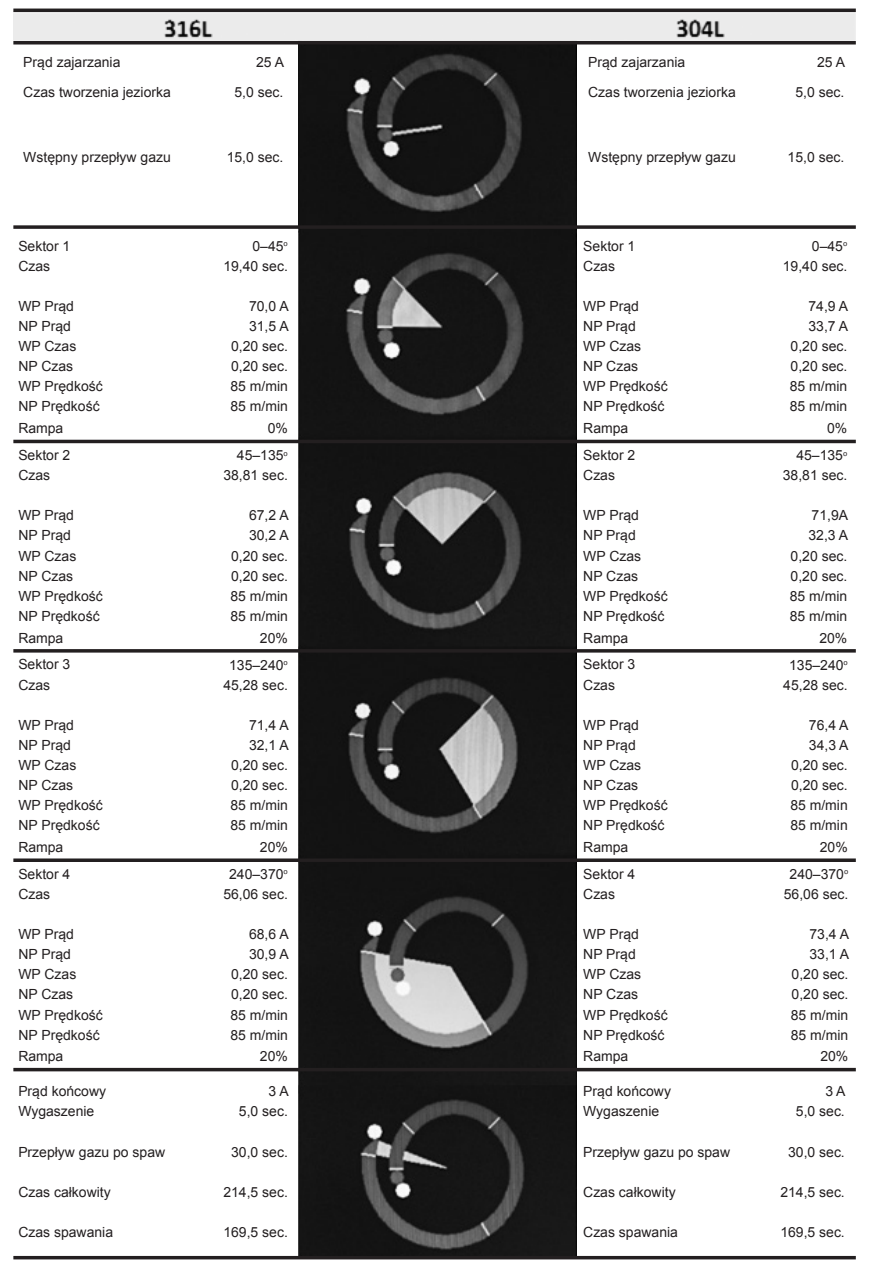

Rys. 1. Parametry spawania w poszczególnych sektora obwodu $0-370^{\circ}$

Fig. 1. Welding parameters in specific circuit sectors $0-370^{\circ}$

\section{Warunki spawania}

Problem czystości gazu formującego jest istotny, a jego kontrola może nastręczać trudności zwłaszcza w przypadku spawania orbitalnego rur instalacji, która została już częściowo wstępnie sczepiona. Tak przygotowany do spawania rurociąg jest wypełniany gazem formującym i zwykle tylko w określonych miejscach za pomocą czujnika można określić stężenie tlenu resztkowego w rurociągu. W ramach eksperymentu wykonano złącza próbne na rurach stalowych w gatunku 304L oraz 316L wg AISI (wg EN10088 1.4306 oraz 1.4404; wg DIN X2CrNi19-11 oraz X2CrNiMo17-12-2) z różnym stężeniem tlenu (6 ppm oraz 500 ppm) w gazie formującym. Średnica zewnętrzna rur wynosiła 70 mm, grubość ścianki $2 \mathrm{~mm}$. Spawano bez materiału dodatkowego, jako gaz osłonowy i formujący stosowano argon 99,995\% (I1 wg PN-EN ISO 14175). Przed przystąpieniem do spawania rurociągu przepłukano wnętrze rury gazem formującym. Natężenie przepływu gazu płuczącego wynosiło $10 \mathrm{l} / \mathrm{min}$. Po osiągnięciu zaplanowanego na potrzeby eksperymentu stężenia tlenu w gazie (argonie) formującym w rurociągu zmniejszono przepływ do wartości ok. $2 \mathrm{l} / \mathrm{min}$ ze względu na konieczność utrzymania nieznacznego nadciśnienia wewnątrz rurociągu. Bezpośrednio po spawaniu utrzymywano niewielki przepływ gazu formującego, aż do momentu, gdy temperatura złącza osiągnęła wartość poniżej $200^{\circ} \mathrm{C}$.

Kąt wierzchołkowy nietopliwej elektrody wolframowej wynosił $30^{\circ}$ (koniec elektrody stępiony), długość łuku $1,5 \mathrm{~mm}$, elektroda zorientowana prostopadle do stycznej i do tworzącej rury. Na rysunku 1 przedstawiono zestaw parametrów spawania.

Złącze podzielono na 4 sektory, dla których parametry spawania zostały dobrane z bazy danych synergicznego systemu sterowania. Największe natężenie prądu spawania stosowano w sektorze 3 , w pozycji pionowej z góry do dołu, co jest związane z grawitacyjnym opadaniem jeziorka ciekłego metalu, w związku z czym potrzebne jest sto-

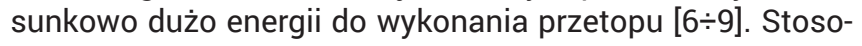
wano impulsowe zasilanie łuku o natężeniu prądu impulsu ok. $70 \mathrm{~A}$ i natężenia prądu bazowego ok. $30 \mathrm{~A}$ dla stali 304L i ok. 5\% mniej dla stali 316L (z kilkuprocentowymi zmianami w sektorach). Czas trwania obu faz cyklu był równy i wynosił 0,2 s. Prędkość spawania na całym obwodzie wynosiła $85 \mathrm{~mm} / \mathrm{min}$. Zakładka końca spoiny na jej początek sięga $20 \%$ długości pierwszego sektora. Natężenie prądu podczas wygaszania łuku wynosiło $3 \mathrm{~A}$, a czas $5 \mathrm{~s}$. Bezpośrednio po zakończeniu spawania, jeszcze przez 30 s. utrzymywany był stały przepływ gazu osłonowego, aby umożliwić wystygnięcie katody i spoiny w gazie obojętnym. Całkowity czas procesu spawania razem z początkowym i końcowym przepływem gazu wynosi 214,5 s. tj. 3,5 min i jest on ok. 2 razy krótszy od czasu potrzebnego do ręcznego wykonania spawania przez doświadczonego spawacza.

Wykonano próby spawania dla stężenia tlenu resztkowego w gazie formującym w wysokości 6 ppm i 500 ppm. Lico wszystkich wykonanych spoin jest czyste i bez widocznych przebarwień. Podczas spawania, od strony lica była pełna (beztlenowa) ochrona gazowa. Elektroda poruszała się w zamkniętej komorze wypełnionej argonem ze stałym przepływem gazu.

Próby spawania wykonano przy użyciu systemu do spawania orbitalnego Orbimat $165 \mathrm{CA}$, opartego na głowicy Orbiweld $76 \mathrm{~S}$ z wodnym chłodzeniem, opisanym w publikacji [3].

Do pomiaru stężenia tlenu resztkowego zastosowano urządzenie Oxy Integral Oxygen Analyser firmy Orbitec. Zakres pomiarowy tego urządzenia wynosi $5 \div 999$ ppm (part per milion - cząstek tlenu na milion; $1 \mathrm{ppm}=0,000001$ ). Kryteria akceptowalności wykonanych złączy opisano w pracy [3]. 


\section{Badania mikrostrukturalne złączy stali 304}

Na rysunku 2 pokazano mikrostrukturę spoiny stali 304L wykonanej ze stężeniem tlenu 6 ppm w gazie formującym. W osi spoiny występują ziarna równoosiowe (tzw. strefa kryształów równoosiowych), gdzie ziarna moją stosunkowo większą swobodę wzrostu. Krystality od linii wtopienia, gdzie zaczyna się zarodkowanie od powierzchni stałej są nieregularne, ponieważ kolejne powstałe dendryty nakładają się tam na siebie, wzajemnie się zniekształcając, są również skierowane ku środkowi, tzn. rozrastają się w kierunku uprzywilejowanym energetycznie, tj. w kierunku odprowadzania ciepła. Jest to tzw. strefa kryształów słupowych. Ślady po krystalizacji spoiny skierowane ku górze, świadczą o odpowiednich proporcjach głębokości do szerokości spoiny. Taka krystalizacja zapobiega zamknięciu ciekłego metalu wewnątrz spoiny, przez co uniemożliwia chemiczną

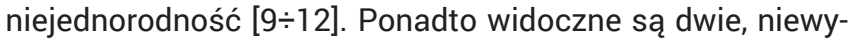
raźne linie wtopienie w kolejne, zastygnięte jeziorka ciekłego metalu. Główna linia wtopienia w materiał rodzimy jest dość szeroka i nieregularna. Może ona również posiadać podwyższoną zawartość ferrytu $\delta$ co jest charakterystyczne dla spoin, których krystalizacja rozpoczyna się od ferrytu $\delta$. Mechanizm tworzenia się tego obszaru wygląda następująco: (1) na skutek wysokiej temperatury, w pobliżu linii wtopienia rozpoczyna się przemiana $\mathrm{Y} \rightarrow \overline{0}$, (najczęściej na istniejących już ziarnach ferrytu $\delta$ ), która postępuje $w$ obszarach o większej zawartości chromu; (2) w czasie szybkiego chłodzenia spoiny, w obszarach tych nie nadąża dokonać się przemiana powrotna $\delta \rightarrow \gamma$, przez co nie uzyskują struktury równowagowej, a co za tym idzie, zawartość ferrytu $\delta$ jest w nich podwyższona [12]. Podwyższona wartość ferrytu powoduje mniejszą odporność na korozję złącza spawanego stali 304L. SWC posiada szerokość ok. 0,6 mm.

Poniższej przedstawiona została analiza geometryczna wykonanych złączy na podstawie zdjęć metalograficznych próbek pobranych w drugim sektorze spoiny (patrz rys. 1) oraz analiza makroskopowa lica i grani spoiny wraz z oceną powstałych przebarwień. Analizie poddano obszar sektora 2. ponieważ do jego wykonania stosowana jest wyższa
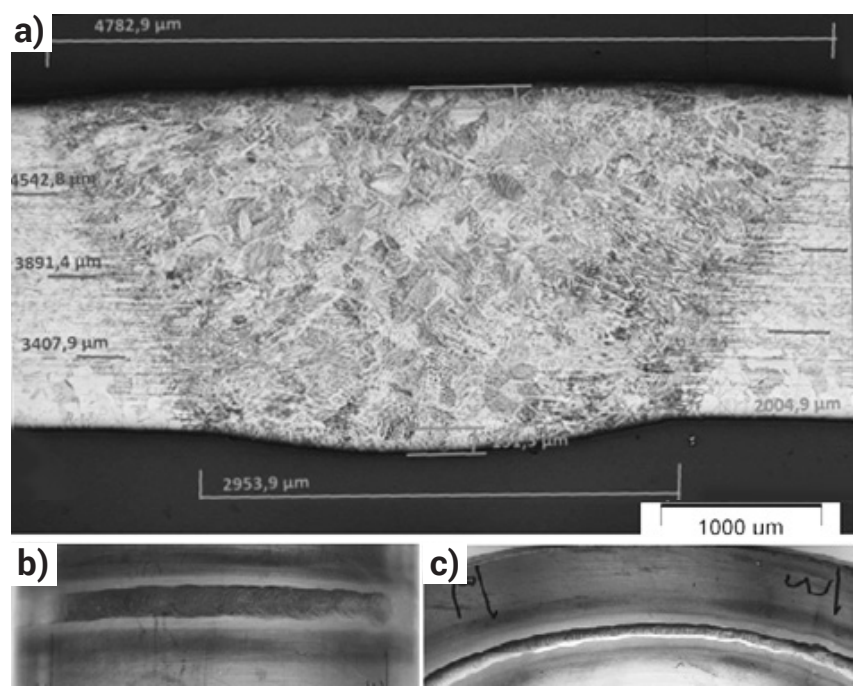

Rys. 2. Spoina z sektora 2 złącza ze stali $304 \mathrm{~L}$ wykonanego przy stężeniu tlenu resztkowego 6 ppm w gazie formującym, a) geometria i mikrostruktura spoiny, b) widok lica spoiny, c) widok grani spoiny Fig. 2. Metallographic picture in sector 2 of $304 \mathrm{~L}$ stainless steel weld formed at a concentration of $6 \mathrm{ppm}$ of residual oxygen in the forming gas, a) geometry and microstructure of weld, b) weld face appearance, $c$ ) the appearance of the weld root wartość energii liniowej spawania co wiąże się ze wzrostem powinowactwa chemicznego tlenu do składników stali.

Wykonanie połączenia stali 304L przy stężeniu tlenu resztkowego w gazie formującym w wysokości 6 ppm pozostawia czystą i białą grań bez przebarwień (rys. 2). Rysunek 3 obrazuje stan złącza spawanego stali 304L wykonanego ze stężeniem tlenu 500 ppm w gazie formującym. Przy tej wielkości grań spoiny posiada znaczne naloty barwne.

Lico spoiny sektora 2 (rys. 2b) w zasadzie o stałej szerokości 4,8 mm na całej długości sektora 2. Dopiero podczas przejścia z sektora 2 na 3 następuje zwiększenie szerokości lica. Grań (rys. 2c) o stałej szerokości 2,9 mm, cieńsza niż w sektorze 1. o 0,6 mm,

Grubość spawanego materiału wynosi około $2 \mathrm{~mm}$ i jest ona zgodna z klasą wykonania T3 wg PN-EN ISO 1127:1999. Lico spoiny jest szersze o $1,8 \mathrm{~mm}$ od grani. Wtopienie jest równomierne, liniowe i symetryczne, nie występuje charaktrystyczny dla spawania w osłonie argonu kształt spoiny w postaci kielicha. Lico i grań spoiny mają niewielkie nadlewy wielkości odpowiednio 0,12 mm i 0,15 mm, mieszczą się one w dopuszczalnym zakresie podanym w ASME BPE-2007. Na długości spoiny zaobserwowano niewielkie przesunięcie od osi wzdłużnej, spowodowane przez nieznaczne przesadzenie ruru. Przesunięcie to mieści się w dopuszczalnym zakresie wg ASME BPE -2007. Szerokość spoiny jest zmienna nawet w obszarze jednego sektora parametrów spawania. Spoina ma tendencję do odchylania się od osi złącza na niewielkie wartości dopuszczalne w normie ASME BPE-2007. Ponadto prążki na licu są w kształcie łuków owalnych, rozmieszczonych na długości w sposób niesymetryczny i nierównomierny.
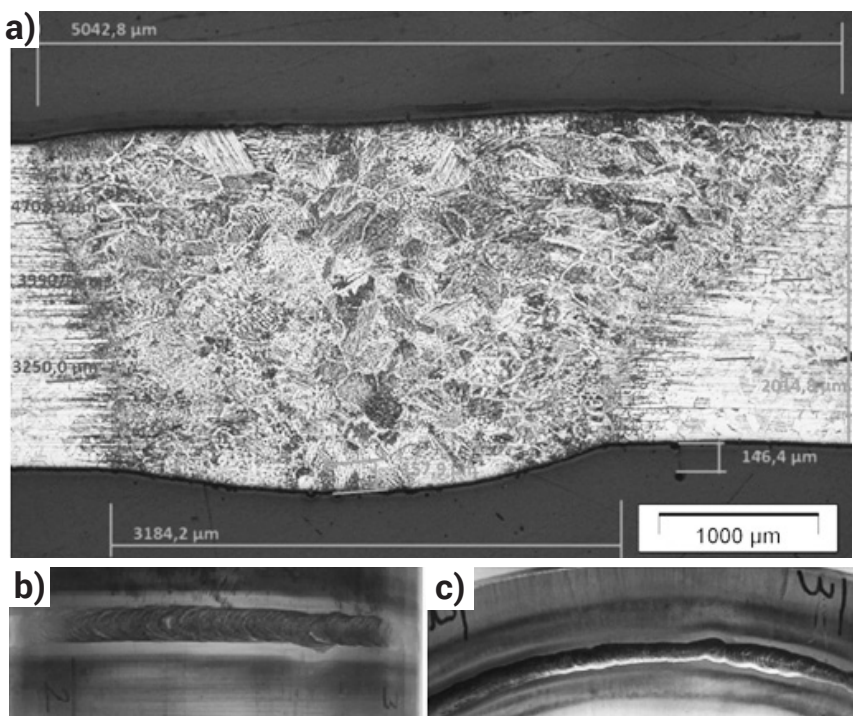

Rys. 3. Spoina z sektora 2 stali 304L wykonana przy stężeniu tlenu resztkowego 500 ppm w gazie formującym, a) geometria i mikrostruktura spoiny, b) widok lica spoiny, c) widok grani spoiny

Fig. 3. Metallographic picture sector 2 of $304 \mathrm{~L}$ stainless steel weld formed at a concentration of $500 \mathrm{ppm}$ of residual oxygen in the forming gas. a) geometry and microstructure of weld, b) weld face appearance, $c$ ) the appearance of the weld root

Lico spoiny wykonanej przy stężeniu 500 ppm tlenu resztkowego w gazie formującym (rys. 3b) w pierwszej części sektora 2 ma stałą szerokość ok. 4,4 mm. Linie graniczne lica spoiny są proste, co świadczy o stabilnym łuku elektrycznym, a także o braku odchyleń od osi złącza. W drugiej części sektora 2 odnotowano zwiększenie szerokości lica do $5 \mathrm{~mm}$ i jego odchylenie od osi złącza (widać je również poniżej, na zgładzie metalograficznym). Jest to tylko miejscowe odchylenie, po którym szerokości lica wraca 
do poprzedniej wartości. Lico spoiny jest płaskie, z widocznym przesadzeniem łączonych rur. Ślady po krystalizacji punktowych jeziorek spawalniczych są nieregularne. Grań spoiny w pierwszej części sektora 2 ma stałą szerokość, jak w sektorze 1 - ok. 3,4 mm. Widoczne jest miejscowe odchylenie grani od osi złącza, które następuje w tym samym miejscu co odchylenie lica. W tym miejscu grań zmniejsza swoją szerokość do 3,2 mm. W dalszej części grań spoiny wraca do osi, zwiększając swoją szerokość. Przy zmianie parametrów z sektora 2 na sektor 3 następuje znaczne zmniejszenie szerokości grani oraz jej przebarwienia od koloru ciemno-niebieskiego (na początku sektora) przez fioletowo/purpurowy (na jego środku), do szarożółto-brunatnego na końcu tego sektora. SWC w sektorach 2 i 3 ma znacznie mniejsze przebarwienie niż w sektorze 1.

Grubość spawanego materiału wynosi $2,01 \mathrm{~mm}$ i jest ona zgodna z klasą wykonania T3 wg PN-EN ISO 1127:1999. Badany wycinek spoiny (rys. 3a) został pobrany w miejscu odchylenia się spoiny, gdzie lico jest szersze o 1,9 mm od grani (jest to właśnie skutkiem odchylenia łuku od osi złącza). Również z tego powodu nierównomierne jest wtopienie, a przesunięcie lica w prawą stronę znacznie widoczne. Kształt wtopienia z obu stron jest charakterystyczny dla spawania w osłonie argonu, spoina ma wygląd kielicha. Należy również zauważyć znaczne przesunięcie łączonych ścianek o ok. 0,15 mm, co jednak mieści się w dopuszczalnym zakresie podanym w ASME BPE-2007. Od strony grani występuje nadlew wielkości 0,16 mm, mieści się on $\mathrm{w}$ dopuszczalnym zakresie. Biorąc pod uwagę przesunięcie ścianek łączonych elementów, lico spoiny można ocenić jako płaskie. Pomimo poprawności geometrycznej spoiny, jest ona niezgodna ze względu na występujące nadmierne przebarwienie grani i SWC (wg AWS D18.2:2009) powstałe w wyniku oddziaływania tlenu na spoinę.

\section{Badania mikrostrukturalne złączy stali 316L}

Na rysunku 4 pokazano mikrostrukturę spoiny stali 316L wykonanej ze stężeniem tlenu 6 ppm w gazie formującym, która jest istotnie odmienna od struktury złącza stali 304L wykonanej w podobnych warunkach, opisanej powyżej. W spoinie stali 316L zaobserwowano dwa różne strukturalnie obszary, które są zależne od gradientu temperatury i prędkości chłodzenia. W związku z tym że w środku spoiny jest mniejszy gradient temperatury i mniejsza prędkość chłodzenia, powstała struktura jest bardziej drobnoziarnista i regularna, dendrytyczna - równoosiowa. Tworzenie się stref równoosiowych $w$ osi spoiny wynika również $z$ heterogenicznego zarodkowania. Zarodki krystalizacji powstają na wcześniej skrystalizowanych jeziorkach ciekłego metalu topionego prądem impulsowym. W strefach wtopienia struktura ma już większe i wyraźnie podłużne ziarna. W tym miejscu struktura jest kolumnowo-dendrytyczna. Dzieje się tak, ponieważ kolejne ziarna podczas krystalizacji blokują się wzajemnie, zniekształcając się oraz wydłużając. Mimo tego struktura dalej pozostaje stosunkowo drobnoziarnista. Na rysunku 4 widać ślady rozrostu ziaren ku górnej części spoiny, w kierunku działania źródła ciepła, prostopadle do linii wtopienia, co świadczy m.in. również o odpowiednim stosunku szerokości do wysokości spoiny. Na obrazie mikrostruktury widać kilka linii wtopienia, ponieważ podczas spawania prądem pulsacyjnym spoina jest zbiorem połączonych ze sobą pojedynczych jeziorek ciekłego metalu, które są wtopione w siebie i materiał rodzimy. SWC jest minimalna - ok. 0,3 mm. W środkowej części spoiny przy licu i grani widać ślady po przegrzaniu materiału.
Na rysunku 4 pokazano lico spoiny z sektora 2, płaskie o stałej szerokości 4,7 mm, z równymi odstępami pomiędzy prążkami na licu. Grań spoiny o stałej szerokości 3,3 mm z niewielkim zwężeniem w połowie sektora 2 . Grań ma zauważalne uwypuklenie na całej długości sektora, mniejsze w jego drugiej połowie. Uwypuklenie to jest spowodowane m.in. oddziaływaniem siły grawitacji na jeziorko ciekłego metalu.

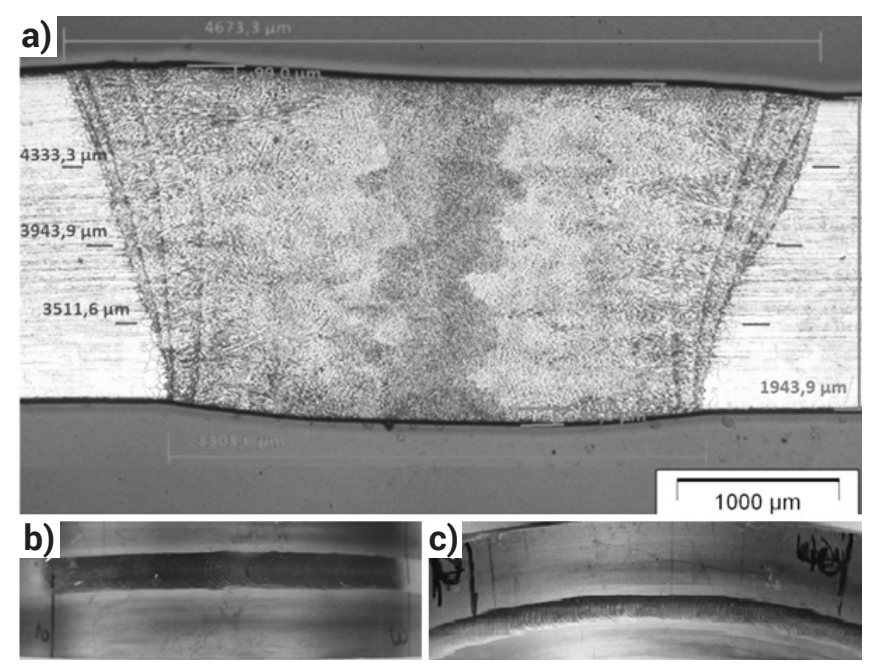

Rys. 4. Spoina z sektora 2 złącze ze stali $316 \mathrm{~L}$ wykonane przy stężeniu tlenu resztkowego 6 ppm w gazie formującym, a) geometria spoiny oraz mikrostruktura, b) wygląd lica spoiny, c) wygląd grani spoiny

Fig. 4. Metallographic picture in sector 2 of $316 \mathrm{~L}$ stainless steel weld formed at a concentration of $6 \mathrm{ppm}$ of residual oxygen in the forming gas, a) geometry and microstructure of weld, b) weld face appearance, $c$ ) the appearance of the weld root

Grubość spawanego materiału wynosi ok. 1,94 mm i jest ona zgodna z klasą wykonania T3 wg ISO 1127. Lico spoiny jest szersze o 1,4 mm od grani. Wtopienie jest prawidłowe z obu stron, jednakże należy zaznaczyć, że z prawej strony mamy kształt kielicha, a lewa strona nie jest symetryczna. Po obu stronach spoiny są niewielkie nadlewy rzędu setnych części milimetra. Mieszczą się one w dopuszczalnym zakresie podanym amerykańską normą ASME BPE-2007. Na długości spoiny widać niewielkie przesunięcia rzędu setnych części milimetra (większe niż w pierwszym sektorze). Przesunięcie to jest akceptowalne, mieści się w dopuszczalnym zakresie. Spoina w sektorze drugim jest akceptowalna z punktu widzenia geometrii i przetopu.

Na rysunku 5 pokazano mikrostrukturę spoiny stali $316 \mathrm{~L}$ wykonanej przy stężeniu tlenu w gazie formującym 500 ppm. Lico jest o stałej szerokości ok. $5 \mathrm{~mm}$ z równymi odstępami pomiędzy prążkami pozostałymi po zastygnięciu jeziorek ciekłego metalu. W górnej części spoiny ma miejsce nierównomierna szerokość lica spoiny. Z tego miejsca został pobrany wycinek, na zgład metalograficzny. Szerokość lica wynosi $5,8 \mathrm{~mm}$. Błądzenie łuku ma swoje odzwierciedlenie w grani spoiny, gdzie mamy miejscowe zmniejszenie szerokości. Tuż przed zmianą parametrów lico spoiny się wyrównuje i spoina wraca do stałej szerokości. Lico spoiny jest płaskie w całym sektorze. Grań spoiny (rys. 5c) o stałej szerokości ok. 3,5 $\mathrm{mm}$ do kąta 90 stopni od położenia początkowego. Grań ma zauważalne uwypuklenie na całej długości sektora 2, mniejsze w jego drugiej połowie. W drugiej części sektora 2 następuje zwężenie grani i miejscowy brak przetopu. Przebarwienia występują na całej długości sektora na grani oraz w SWC. Mają one kolor ciemno i jasno-niebieski. Przy zmianie parametrów z sektora 2 na 3 zmienia kolor na fioletowy. Widoczne przebarwienie wg amerykańskiej normy AWS D18.2:2009 nie dopuszcza tej spoiny do użytkowania. 
Grubość spawanego materiału wynosi ok. 1,95 mm i jest ona zgodna z klasą wykonania T3 wg ISO 1127. W miejscu błądzenia łuku lico spoiny jest szersze o 2,8 $\mathrm{mm}$ od grani, od strony lica jest w zasadzie płaskie. Grań spoiny ma nadlew wielkości 0,17 mm. Spoina w przekroju ma kształt kielicha, charakterystyczny podczas spawania w osłonie argonu. Ze względu na przebarwienie spoina jest nieakceptowalna.

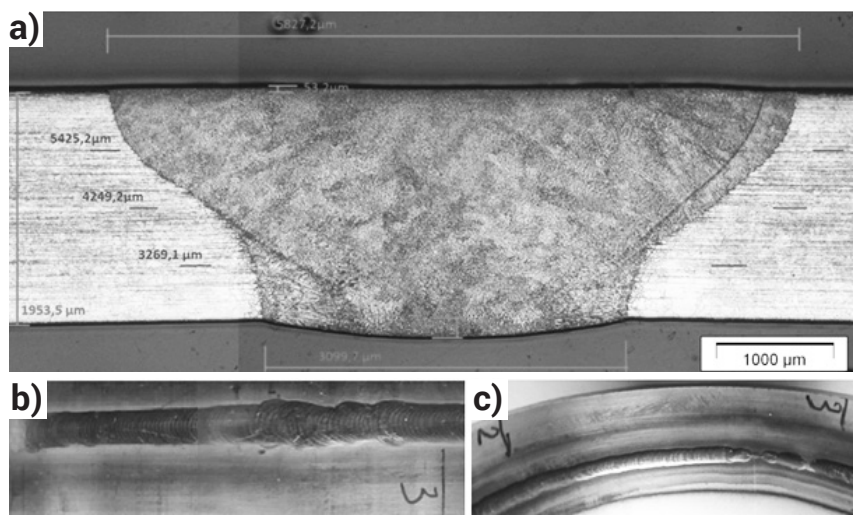

Rys. 5. Zdjęcie metalograficzne zgładu z sektora 2 złącza ze stali $316 \mathrm{~L}$ wykonanego przy stężeniu tlenu resztkowego 500 ppm w gazie formującym, a) geometria spoiny oraz mikrostruktura, b) wygląd lica spoiny, c) wygląd grani spoiny

Fig. 5. Metallographic picture in sector 2 of $316 \mathrm{~L}$ stainless steel weld formed at a concentration of $500 \mathrm{ppm}$ of residual oxygen in the forming gas, a) geometry and microstructure of weld, b) weld face appearance, $c$ ) the appearance of the weld root

\section{Pomiary twardości w osi pionowej spoiny oraz w obszarze grani}

Pomiary twardości materiału spoiny wykonano w dwóch kierunkach, w kierunku osi pionowej (wysokości spoiny) lico-grań oraz w obszarze grani na linii MR-SWC-spoina-SWCMR. Wykonane zostały po 4 pomiary dla jednego punktu. $\mathrm{Na}$ wykresie przedstawiono wartość średnią oraz jej odchylenie standardowe przy 95\% poziomie ufności. Na rysunku 6 przedstawiony został rozkład twardości wykonany na przekrojach poprzecznych złączy w sektorze 2 dla wszystkich czterech wariantów. W złączach stali $316 \mathrm{~L}$ zaobserwowano nieznaczne zmiany twardości przy stosunkowo niskim odchyleniu standardowym. W złączach stali 304L twardość jestz reguły znacznie wyższa przy dużym odchyleniu standardowym od wartości średniej. Zaobserwowano również znaczny wzrost twardości wraz ze wzrostem stężenia tlenu w gazie formującym.

Na rysunku 7 przedstawiono zestawienie rozkładów twardości od strony grani w linii równoległej do powierzchni rur. We wszystkich przypadkach są wyraźne spadki twardości w obszarach SWC. W złączach ze stali $316 \mathrm{~L}$ nie zaobserwowano istotnego wzrostu twardości w spoinie zarówno dla niższego, jak i wyższego stężenia tlenu w gazie formującym. Uwagę zwraca natomiast duży wpływ obecności tlenu w gazie formującym na twardość w spoinach stali 304L. Stężenie 6 ppm tlenu powoduje wzrost twardości w obszarze grani do ok. $190 \mu \mathrm{HV0}, 1$, a wzrost stężenia tlenu do 500 ppm skutkuję osiągnięciem maksymalnej twardości około $250 \mu \mathrm{HV} 0,1$.

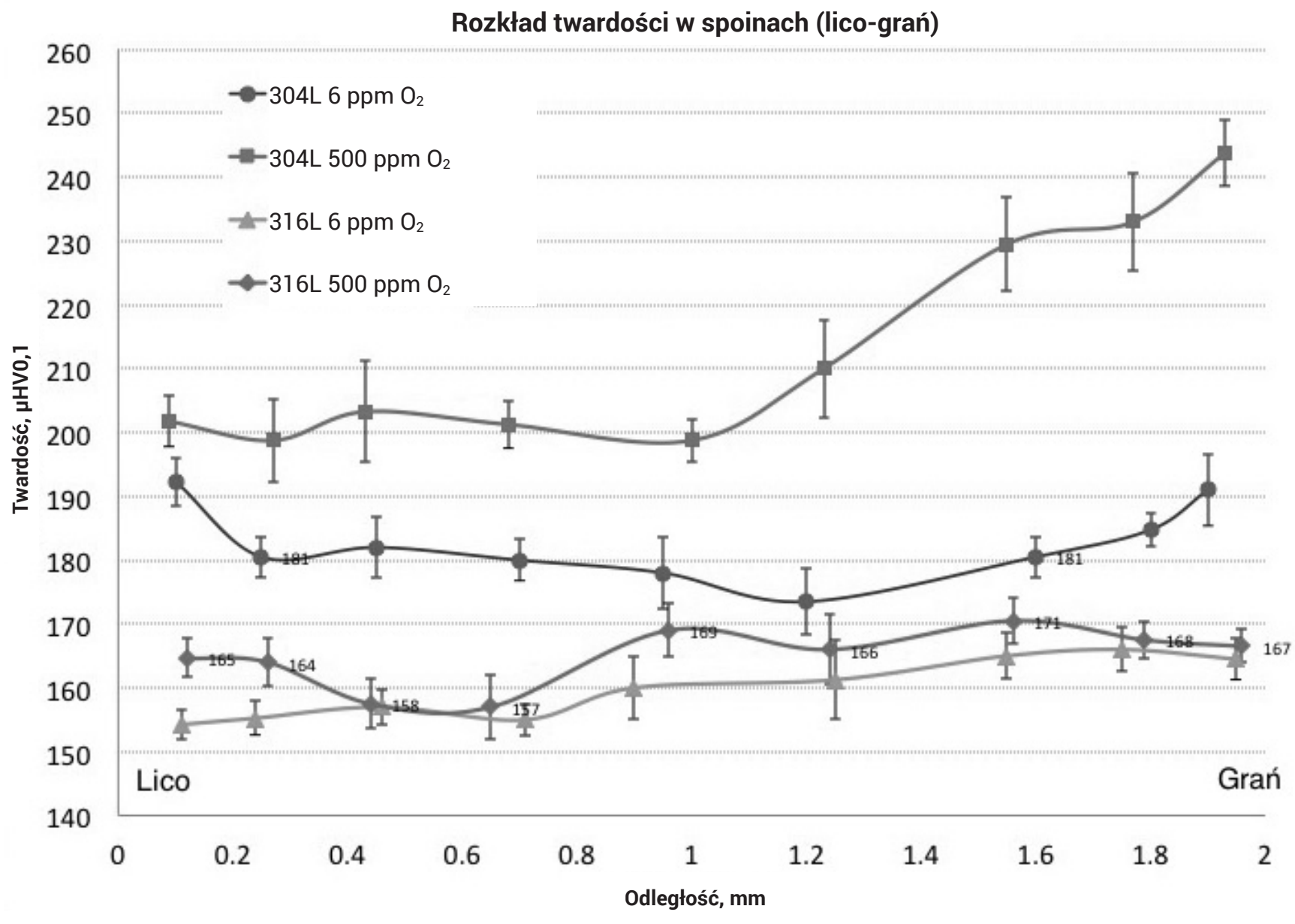

Rys. 6. Zdjęcie metalograficzne zgładu z sektora 2 złącza ze stali $316 \mathrm{~L}$ wykonanego przy stężeniu tlenu resztkowego 500 ppm w gazie formującym, a) geometria spoiny oraz mikrostruktura, b) wygląd lica spoiny, c) wygląd grani spoiny

Fig. 6. Metallographic picture in sector 2 of $316 \mathrm{~L}$ stainless steel weld formed at a concentration of 500 ppm of residual oxygen in the forming gas, a) geometry and microstructure of weld, b) weld face appearance, c) the appearance of the weld root 




Rys. 7. Rozkład twardości w przekroju poprzecznym złącza w obszarze grani dla złączy ze stali 304L i 316L wykonanych przy $6 p p m$ i 500ppm zawartości tlenu w gazie formującym

Fig. 7. Hardness distribution in cross-section in root area in joints of $304 \mathrm{~L}$ and $316 \mathrm{~L}$ obtained with $6 \mathrm{ppm}$ and 500 ppm oxygen in forming gas

\section{Podsumowanie i wnioski}

- Na rysunkach 6 i 7 przedstawiono rozkłady twardości, z których wynika, że wzrost stężenia tlenu z 6 ppm do 500 ppm w gazie formującym spowodował istotny wzrost twardości w spoinie ze stali 304L, natomiast w przypadku spoiny ze stali 316L tak istotnego wpływu stężenia tlenu resztkowego na twardość spoiny nie zarejestrowano.

- Złącza obu stosowanych gatunków stali wykonane przy stężeniu tlenu w gazie formującym - 6 ppm, charakteryzują się ogólnie większą jednorodnością twardości w przekroju poprzecznym.

- Wysoka twardość spoin ze stali 304L wykonanych przy stężeniu tlenu resztkowego w gazie formującym - 500 ppm, może mieć istotny wpływ na właściwości mechaniczne wykonanych złączy, w tym np. wytrzymałość zmęczeniową.

- Należy bezwzględnie przestrzegać zasad właściwego wypełnienia rurociągu gazem formującym i zabezpieczać miejsca spawane przed dostępem powietrza.

- Repasywacja nadmiernie utlenionej stali może częściowo przywrócić odporność korozyjną utlenionej powierzchni, natomiast utwardzenie obszaru grani powstałe poprzez nadmierne utlenienie jest nieodwracalne.

\section{Literatura}

[1] T. Chmielewski: Projektowanie procesów technologicznych - spawalnictwo, Oficyna Wydawnicza Politechniki Warszawskiej, Warszawa, 2013

[2] M. Gucwa, R. Bęczkowski, M. Stefański: Spawanie orbitalne wężownic ze stali VM12-SHC, Przegląd Spawalnictwa, vol. 87(10), s.120-123, 2015.

[3] M. Drabarz, T. Chmielewski, Wpływ tlenu resztkowego w gazie formującym na wybrane właściwości grani złącza stali 304L spawanego TIG orbitalnie, Przegląd Spawalnictwa, vol. 89 (1), s. 45-50, 2017.

[4] G. Rogalski, J. Łabanowski, D. Fydrych, A. Świerczyńska: Wpływ obróbki cieplnej na właściwości spawanych austenitycznych rur wymienników ciepła, Przegląd Spawalnictwa, vol. 86(6), s. 24-31, 2014.

[5] T. Sałaciński, W. Sosnowski: Wykorzystanie źródeł laserowych led do spajania cienkościennych elementów z blach nierdzewnych, Przegląd Spawalnictwa, vol. 88 (12), s. 10-14, 2016.

[6] K. Ferenc, T. Chmielewski, i inni: Technika spawalnicza w praktyce poradnik inżyniera, konstruktora i spawacza, Verlag Dashofer, 2009.

[7] J. Górecki, T. Chmielewski, A. Kolasa: Automatyczne spawanie łukiem krytym elementów rurociągów ze stali nierdzewnej 347, Spajanie Metali i Tworzyw w Praktyce 11(4), s. 16-19, 2005.
[8] M. Węglowski, T. Chmielewski, K. Kudła: Ocena wydajności spawania niskoenergetycznego procesu SpeedRoot w pozycji PG, Przegląd Spawalnictwa, vol. 83(12), s. 26-30, 2011.

[9] T. Chmielewski, M. Węglowski, K. Kudła: Spawanie w pozycji PF metodą MMA z wykorzystaniem nowej funkcji UP w zasilaczach inwertorowych zbudowanych w technice MICOR, Przegląd Spawalnictwa, vol. 86(9), s. $45-49,2014$.

[10] AWS D18.2:2009, Guide to Weld Discoloration Levels on Inside of Austenitic Stainless Steel Tube, American Welding Society 2009.

[11] K. Kimbrel: Determining Acceptable Levels of Weld Discoloration on Mechanically Polished and Electropolished Stainless Steel Surface, [w:] Pharmaceutical Engineering, vol. 31 no. 6, December 2011.

[12] E. Tasak: Metalurgia Spawania, Wydawnictwo „Jak" Andrzej Choczewski, Kraków 2008. 